\title{
Farmers' awareness of the potential of vetiver grass for soil erosion control on Ogbomoso Agricultural Zone farmlands, south-western Nigeria
}

\author{
E. A. Ewetola ${ }^{1 *}$, G. E. Fanifosi ${ }^{2}$ (D) A. A. Ezekiel ${ }^{2}$, A. A. Adetona ${ }^{1}$, F. M. Oyewole ${ }^{1}$, N. M. Onatoye ${ }^{1}$, I. T. Idowu ${ }^{1}$
} and A. K. Akinniku'

\begin{abstract}
Background: Soil degradation remains a serious threat to agricultural production. With increase downpour due to climate change effect, more farmlands are exposed to erosion. Therefore, ecologically sound strategies for erosion control are indispensable to farmers, to boost agricultural productivity.

Results: A multistage sampling technique was used to select the respondents for this study, and descriptive and inferential statistics were adopted to determine the farmers' perception of the awareness, adoption and use of vetiver grass technology in controlling erosion in the study area. A total of four hundred valid questionnaires were subjected to analysis and the result shows that most of the farmers (29\%) were between the ages of 41 and 50 years and the average age of the respondents stood at 45.5 years, implying that the farmers were in their productive and active age. Most of the respondents were male and married with an average household size of 5.2. Large number (76\%) of the respondents had formal education, which the level ranged from primary to post-secondary education. Large proportion of the respondents engaged in private business as secondary occupation with an average income of $\$ 84.6$ per cropping season. The effectiveness of vetiver grass adoption and use was significantly influenced by age $(P<0.1)$, gender $(P<0.01)$, marital status $(P<0.05)$, level of education $(P<0.01)$ and income of the respondents $(P<0.05)$. Most of the respondents within the ages of 41-50 years were aware of the erosion control potentials of vetiver grass and adopted the grass because it was cheap and affordable, easy to cultivate and maintain, and readily available and perceived to possess the potential effectiveness to control erosion.
\end{abstract}

Conclusion: Stakeholders are enjoined to increase the awareness of the vetiver grass for increased adoption and utilization, as many farmers were ignorant of the vetiver grass technology for erosion control in the study area.

Keywords: Soil erosion, Vetiver grass, Technology, Usefulness, Ogbomoso Agricultural Zone

*Correspondence: eaewetola@lautech.edu.ng

1 Department of Crop Production and Soil Science, Ladoke Akintola University of Technology, P.M.B 4000, LAUTECH, Ogbomoso, Oyo State, Nigeria

Full list of author information is available at the end of the article

\section{Background}

The concept of soil resources is closely related to livelihood of human kind, because it provides food, clean water and air, and serves as major carrier for biodiversity (Katsuyuki 2009; Keesstra et al. 2016). Soil erosion is a global environmental problem that reduces the productivity of all natural ecosystem and agriculture. Greenfield (2002) posited that it is one of the major problems faced in rainfed agriculture throughout the 
world. The erosivity of rainfall coupled with the inherent low organic matter and low activity clay minerals of tropical soils has resulted to its high erodibility. One of the greatest limiting factors in agricultural production can be linked to water erosion with smallholder farming. In most of the developing countries, soil erosion are on high rates and this may be as a result of intensive cultivation, deforestation, ploughing of marginal lands and extreme climate hazards (Biswas et al. 2015; Colazo and Buschiazzo 2015; Ligonja and Shrestha 2015; Molla and Sisheber 2017). Land degradation caused by soil erosion has been estimated to be about $80 \%$ of agricultural land (Angima et al. 2003; Rodrigo-Comino et al. 2015; Molla and Sisheber 2017). However, the knowledge of rates of soil erosion by water is important on agricultural land, because it determines the long-term sustainability of agricultural practices.

The soil of south-western Nigeria is eroded mainly with water through water erosion as high intensity rainfall removes the top soil (Babalola et al. 2003 and this results to decline in the productivity. The threat to sustainable environmental and agricultural productivity has led to considerable interest in soil conservation technologies that control runoff and erosion. Such erosion measures include tillage, mulch farming, cover crops, alley farming, ridge-furrow system, contour farming, contour bunds, terraces and vegetative barriers. Majority of the erosion control measures mentioned above was associated with one or more problems that made it difficult for farmers to adopt them (Edeoghon et al. 2008; Aina 1989; Babalola and Opara-Nadi 1993; Prosdocimi et al. 2016; Babalola et al. 2003; Osuji and Babalola 1982). For instance, the trend of high cost and unavailability of chemicals (herbicides) in Nigeria put a limitation on the adoption of the notillage technique (Akamigbo 1988), while contour bunding becomes uneconomical when the slope is more than $15 \%$, and terracing has a lot of drudgery inherent in it (Aina 1989). However, a proven solution to erosion and loss of water, soil and nutrient has been found with vetiver grass. In Nigeria, studies have shown that vetiver (Vetiveria nigritana (Benth.) Stapf) grass strips have demonstrated locally their efficiency in curtailing soil erosion and improving crop yield. About 70\% reduction in soil loss, runoff by about $130 \%$ and $50 \%$ increased maize grain yield with vetiver grass strips at $20 \mathrm{~m}$ interval when compared to a control (Babalola et al. 2003). According to the reports of the research of (Oku and Aiyelari 2014 and Ewetola 2017), the grass shows its efficacy in reducing runoff, soil loss, nutrient and improved crop yield. Also, Truong and Loch 2004; Sanguankaeo et al. 2011; Cao et al. 2016 revealed same beneficial effects of the grass but at different degrees.
Vetiver grass (Vetiveria nigritana (Benth.) Stapf) is a multipurpose grass that is well adapted to different environmental conditions. Little homesteads in southwestern Nigeria, vetiver grass is being planted only for termites control (Ewetola et al. 2017) or as ornamentals; many farmers might have not been informed of other agronomic values specifically, as preventive measure to control wearing a way of top soil. As an erosion control strategy, its technology is simple, cheap and eco-friendly. It is believed that vetiver grass planted for erosion control can conserve water, soil and increase yield on the farmers' farmlands and with other benefits accruing from the technology. This research was designed to evaluate farmers' awareness of the usefulness of vetiver for soil erosion control on farmlands in Ogbomoso Agricultural Zone, south-western Nigeria. In order to achieve this aim, this work was set to provide answers to the following questions: (i) What were the farmers' perception on the adoption of vetiver grass for soil erosion control? (ii) What factors influenced the farmers' choice of erosion control? (iii) What level of awareness had the farmers' of the usefulness of vetiver grass for erosion control? (iv) How were the farmers informed of the use of vetiver grass for erosion control? (v) What were the reasons for the farmers' choice of vetiver grass as erosion control measure in the study area?

\section{Methods}

Ogbomoso was a city in southwest Nigeria situated on

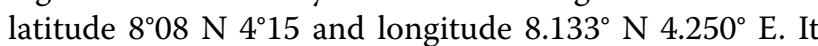
has tropical savanna climate with two distinctive seasons (wet and dry). Ogbomoso Agricultural Development zone of Oyo is one of the four Agricultural Development zones in Oyo State Nigeria. The zone comprises of five Local Government Areas (LGAs), and it is an agrarian area as shown in Fig. 2. Dominant crops cultivated in the zone include maize, cowpea, groundnut, cassava, yam, potatoes and so on. Also, the zone is known for mango and cashew production and livestock farming is also prominent in the area. The agricultural zone was chosen for this study because of many agrarian communities that are under the threat of soil erosion in the zone. Through a multistage sampling, about one-fifth of farmers were randomly selected from each of the three main agrarian LGAs in the study area-One hundred and forty-nine (149) from Ogo-Oluwa, one hundred and forty-three (143) from Oriire and one hundred and sixty-five (165) from Surulere totaling four hundred and fifty-seven (457) farmers. Information through the use of questionnaire was collected on the social and demographic characteristics, farm-level information, awareness and adoption of vetiver grass as a means of erosion control, level/type of damage caused by erosion, knowledge on the use of 
vetiver grass and the usage of the vetiver grass in the study area. The literate farmers were given the questionnaire and were guided in supplying the necessary information, while the non-literate farmers were interviewed. At last, four hundred valid questionnaires were subjected to statistical analysis due to insufficient information provided by the others. The data were analysed with both descriptive, Chi-square analysis and composite score. The descriptive statistics presents the frequency count, percentages and the mean, while the Chi-square establishes the association between the variables tested (Fig. 1).

\section{Model specification}

Chi-square $\left(X^{2}\right)$ statistic is used to investigate whether distributions of categorical variables differ from one another. The equation is stated below;

$$
X^{2}=\frac{\sum(O-E)^{2}}{E}
$$

where $\Sigma$ means to sum up, $\mathrm{O}=$ each Observed (actual) value, $\mathrm{E}=$ each Expected value.

\section{Results}

\section{Socioeconomic characteristics of the respondents}

The result presented in Table 1 shows that 29.25\% of the respondents' age fell within the ages of 41-50, and the average age of the respondents stood at 45.52 . Also, exactly $73 \%$ of the farmers were male and more than $79 \%$ of them were married. Household that were not more than five members had the highest percentage of $55.5 \%$ with the mean household size of 5 ; this indicated that most of the farm families had moderate household size. Secondary education had the highest percentage of $48.25 \%$; this shows that most of the farmers in the study area were literate which helps in adoption of new agricultural innovation (s). The result

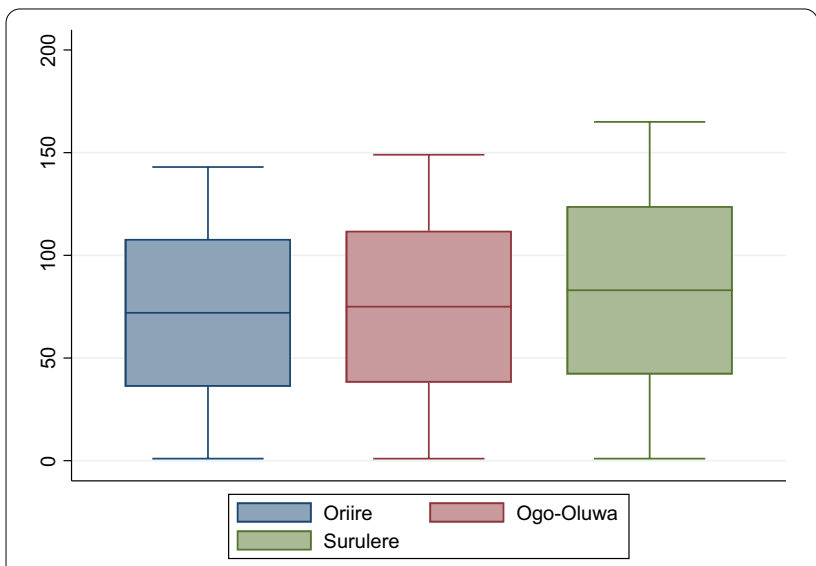

Fig. 1 Distribution of the selected farmers in the study area
Table 1 Socioeconomic characteristics of the respondents $(\mathrm{N}=$ 400). Source: Field Survey, 2018

\begin{tabular}{|c|c|c|}
\hline Socioeconomic characteristics & Frequency & Percentage \\
\hline \multicolumn{3}{|l|}{ Age } \\
\hline$\leq 30$ & 42 & 10.50 \\
\hline $31-40$ & 111 & 27.75 \\
\hline $41-50$ & 117 & 29.25 \\
\hline $51-60$ & 87 & 21.75 \\
\hline Above 60 & 43 & 10.75 \\
\hline \multicolumn{3}{|l|}{ Mean $=45.52$} \\
\hline \multicolumn{3}{|l|}{ Gender } \\
\hline Male & 292 & 73.00 \\
\hline Female & 108 & 27.00 \\
\hline \multicolumn{3}{|l|}{ Marital status } \\
\hline Married & 318 & 79.50 \\
\hline Single & 36 & 9.00 \\
\hline Widow & 29 & 7.25 \\
\hline Divorce & 12 & 3.00 \\
\hline Separated & 5 & 1.25 \\
\hline \multicolumn{3}{|l|}{ Household size } \\
\hline$\leq 5$ & 222 & 55.50 \\
\hline $6-10$ & 178 & 44.50 \\
\hline \multicolumn{3}{|l|}{ Mean $=5.23$} \\
\hline \multicolumn{3}{|l|}{ Level of education } \\
\hline No formal education & 96 & 24.00 \\
\hline Primary education & 79 & 19.75 \\
\hline Secondary education & 193 & 48.25 \\
\hline Post-secondary education & 32 & 8.00 \\
\hline \multicolumn{3}{|l|}{ Income (US dollars) } \\
\hline$\leq 200$ & 373 & 93.25 \\
\hline $200-250$ & 7 & 1.75 \\
\hline $251-300$ & 8 & 2.00 \\
\hline $301-350$ & 8 & 2.00 \\
\hline Above 350 & 4 & 1.00 \\
\hline \multicolumn{3}{|l|}{ Mean $=84.6$} \\
\hline \multicolumn{3}{|l|}{ Secondary occupation } \\
\hline Civil servant & 52 & 13.00 \\
\hline Private business & 329 & 82.25 \\
\hline Student & 19 & 4.75 \\
\hline Total & 400 & 100.00 \\
\hline
\end{tabular}

$\$ 1=\mathrm{N} 360$

also shows that the average income of the respondents stood at $\$ 84.6$. About $82 \%$ of the farmers had private business as their secondary occupation; exactly $13 \%$ were civil servants, while only $4 \%$ were students. The result indicated that most of the respondents diversified livelihood income to enhance income generation and mitigate the ripple effect of food insecurity in the study area (Fig. 2). 


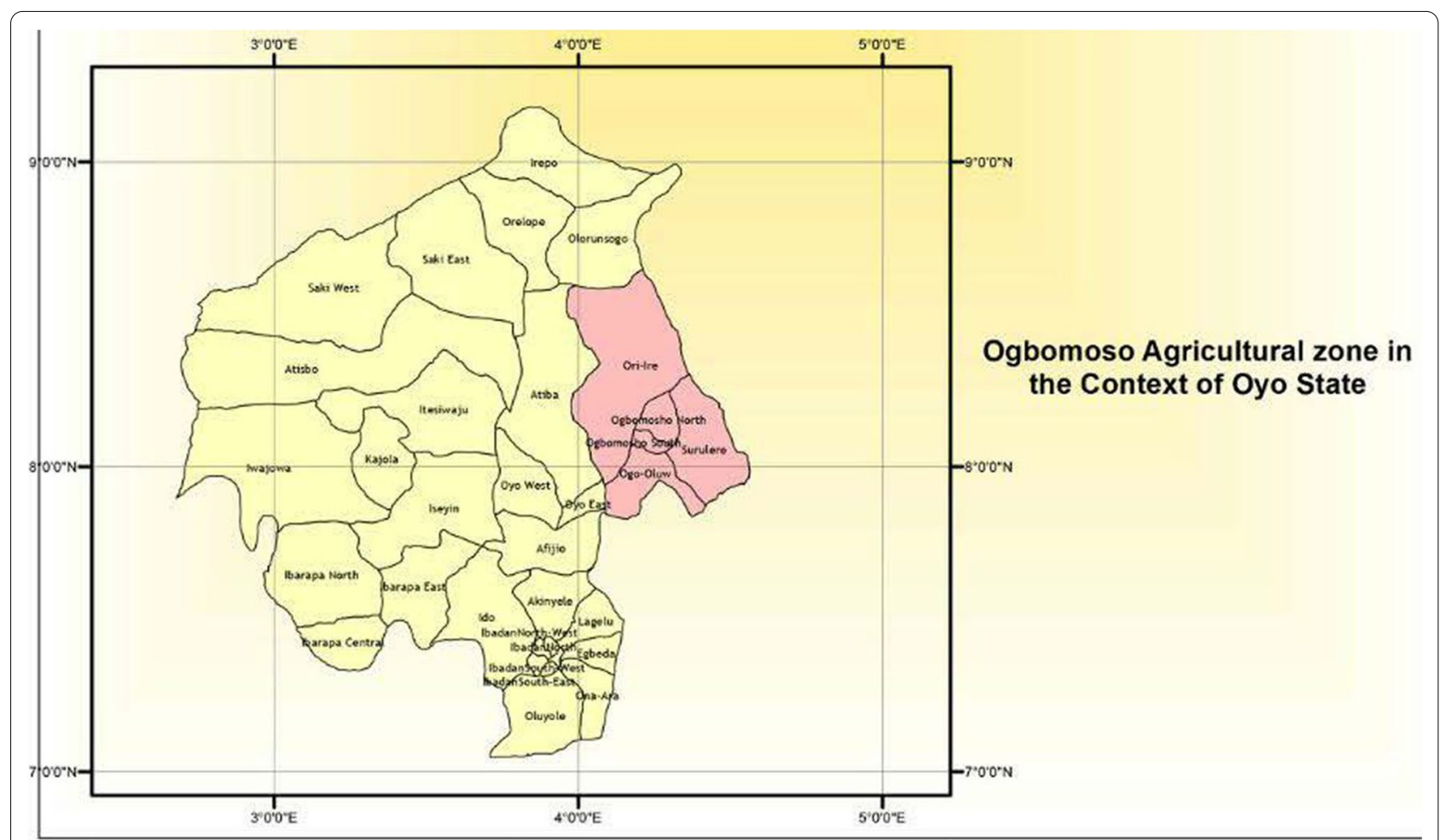

Fig. 2 Map of the study area under Ogbomoso Agricultural Zone [adapted from Ewetola et al. (2017)]

\section{Farmers' awareness of vetiver grass as a means of erosion control.}

Table 2 shows the result of farmers' awareness of vetiver grass as a means of erosion control; from the table, the age of the respondents' shows a significant relationship with the awareness of the respondents of vetiver grass as a means of erosion control at 5\% level. The category of the age with highest percentage was $41-50$ years. About $75 \%$ of the respondents were aware of vetiver grass as a means of erosion control; the gender also had a significant relationship with at $1 \%$ level of significance. Marital status of the respondents was also significant at $5 \%$ level; the result revealed that $77.7 \%$ of the married respondents were aware of the vetiver grass as a means of controlling erosion, while $81 \%$ of the married respondents lacked that awareness. About $11.2 \%$ of the respondents were single, and $7.3 \%$ who were widow were aware of vetiver grass as a means of erosion control. The awareness of the respondents of vetiver grass use as erosion control measure was significantly affected by the coefficient of education at $5 \%$ level $\left(X^{2}=0.2846, P=0.033\right)$; most $(57.5 \%)$ of the farmers with secondary education were aware of vetiver grass as a means of erosion control, while $40.7 \%$ of this same category of respondents were not aware of vetiver's effectiveness for controlling erosion. The coefficient of income of the farmer significantly influenced the awareness of vetiver grass as a means of erosion control at $10 \%$ level. Almost all the farmers (93.9\%) with not more than \$ 200 income were aware of vetiver's potential as a means of erosion control.

\section{Farmers' perceived reasons for the adoption of vetiver grass for controlling erosion on their farmlands}

The result presented in Table 3 shows the farmers' perceived reasons for adoption of vetiver grass for the purpose of erosion control. The result shows that the coefficient of the age was significant at $1 \%$ level; $31.3 \%$ of the respondents within the ages of 41-50 years adopted vetiver grass technology because it was cheap and affordable. About 33\% of the respondents in this category adopted the grass as a result of its ease in cultivation and maintenance. For the effectiveness of the grass in erosion control, 29.5 percentage of the respondents within the ages of 41 and 50 years adopted the technology for this reason and $27.9 \%$ of the respondents between the ages of 51 and 60 years adopted the technology for the above stated reason. Also, 35.3\% of the respondents within the ages of 31-40 years adopted vetiver grass for erosion control because it was readily available and $27.9 \%$ within the ages of 41-50 years adopted vetiver grass technology for the same reason. Most (75.4\%) of the respondents who were male adopted vetiver grass for erosion control 
Table 2 Farmers' awareness of vetiver grass as a means of erosion control. Source: Field Survey, 2018

\begin{tabular}{|c|c|c|c|}
\hline Awareness & Yes & No & Total \\
\hline \multicolumn{4}{|l|}{ Age (years) } \\
\hline$\leq 30$ & $21(11.73)$ & $21(9.50)$ & $42(10.50)$ \\
\hline $31-40$ & $48(26.82)$ & $63(28.51)$ & $111(28.50)$ \\
\hline $41-50$ & $51((28.49)$ & $66(29.86)$ & $117(28.50)$ \\
\hline $51-60$ & $39(21.79)$ & $48(21.72)$ & $87(21.75)$ \\
\hline Above 60 & $20(11.17)$ & $23(10.41)$ & $43(10.75)$ \\
\hline \multicolumn{4}{|c|}{ Linear-by-linear association $0.5921,(P=0.0113)^{* * *}$} \\
\hline \multicolumn{4}{|c|}{ Gender } \\
\hline Male & $134(74.86)$ & $158(71.49)$ & $292(73.00)$ \\
\hline Female & $45(25.14)$ & $63(28.51)$ & $108(27.00)$ \\
\hline \multicolumn{4}{|c|}{ Linear-by-linear association $0.4666(P=0.000)^{* * *}$} \\
\hline \multicolumn{4}{|l|}{ Marital status } \\
\hline Married & $139(77.65)$ & $179(81.00)$ & $318(79.50)$ \\
\hline Single & $20(11.17)$ & $16(7.24)$ & $36(9.00)$ \\
\hline Widow & $14(7.82)$ & $15(6.79)$ & $29(7.25)$ \\
\hline Divorce & $4(2.23)$ & $8(3.62)$ & $12(3.00)$ \\
\hline Separated & $2(1.12)$ & $3(1.36)$ & $5(1.25)$ \\
\hline \multicolumn{4}{|c|}{ Linear-by-linear association $0.0369(P=0.025)^{* *}$} \\
\hline \multicolumn{4}{|c|}{ Household size } \\
\hline$\leq 5$ & $102(56.98)$ & $120(54.30)$ & $222(55.50)$ \\
\hline $6-10$ & $77(43.02)$ & $101(45.70)$ & $178(44.50)$ \\
\hline \multicolumn{4}{|c|}{ Linear-by-linear association $0.0016(P=0.4921)$} \\
\hline \multicolumn{4}{|c|}{ Level of education } \\
\hline No formal education & $27(15.08)$ & $69(31.22)$ & $96(24.00)$ \\
\hline Primary education & $32(17.88)$ & $47(21.27)$ & 79 (19.75) \\
\hline Secondary education & $103(57.54)$ & $90(40.72)$ & $193(48.25)$ \\
\hline Post-secondary education & $17(9.50)$ & $15(6.79)$ & $32(8.00)$ \\
\hline \multicolumn{4}{|c|}{ Linear-by-linear association $0.2846(P=0.033)^{* *}$} \\
\hline \multicolumn{4}{|c|}{ Income per cropping season (US dollars) } \\
\hline$\leq 200$ & $168(93.85)$ & $205(92.76)$ & $373(93.25)$ \\
\hline $201-250$ & $1(0.56)$ & $6(2.71)$ & $7(1.75)$ \\
\hline $251-300$ & $3(1.68)$ & $5(2.26)$ & $8(2.00)$ \\
\hline $301-350$ & $4(2.23)$ & $4(1.81)$ & $8(2.00)$ \\
\hline Above 350 & $3(1.68)$ & $1(0.45)$ & $4(1.00)$ \\
\hline \multicolumn{4}{|c|}{ Linear-by-linear association $0.6391(P=0.100)^{*}$} \\
\hline \multicolumn{4}{|c|}{ Secondary occupation } \\
\hline Civil servant & $33(18.44)$ & $19(8.60)$ & $52(13.00)$ \\
\hline Private business & $133(74.30)$ & $196(88.69)$ & $329(82.25)$ \\
\hline Student & $13(7.26)$ & $6(2.71)$ & $19(4.75)$ \\
\hline Linear-by-linear associationo & & & \\
\hline
\end{tabular}

Figures in parenthesis are percentage

$\$ 1=360$

***,**, ${ }^{*}$ Significant at $1 \%, 5 \%$ and $10 \%$ probability level, respectively

because it was cheap and affordable. Also, 69.2\%, 70.5\% and $70.6 \%$ adopted vetiver grass as a means of erosion control because of its ease in maintenance and cultivation, effective in erosion control and readily availability, respectively. The result further showed that married respondents had the highest percentage for the four reasons tabled as the reasons for the adoption of vetiver grass technology as a means of erosion control with $82.6 \%$ adopted it for being cheap and affordable, $81.5 \%$ adopted the grass technology for its ease of maintenance 
Table 3 Farmers' reasons for the adoption of vetiver grass for erosion control. Source: Field Survey, 2018

\begin{tabular}{|c|c|c|c|c|}
\hline \multirow[t]{2}{*}{ Variables } & \multicolumn{4}{|c|}{ Reasons for the adoption of vetiver grass } \\
\hline & Cheap and affordable & $\begin{array}{l}\text { Easy to maintain } \\
\text { and cultivate }\end{array}$ & $\begin{array}{l}\text { Effectiveness } \\
\text { in erosion control }\end{array}$ & Readily available \\
\hline \multicolumn{5}{|l|}{ Age } \\
\hline$\leq 30$ & $19(9.74)$ & $21(9.95)$ & $11(18.03)$ & $11(16.18)$ \\
\hline $31-40$ & $55(28.21)$ & $69(32.70)$ & $9(14.75)$ & $24(35.29)$ \\
\hline $41-50$ & $61(31.28)$ & $69(32.70)$ & $18(29.51)$ & $19(27.94)$ \\
\hline $51-60$ & $44(22.56)$ & $38(18.01)$ & $17(27.87)$ & $11(16.18)$ \\
\hline Above 60 & $16(8.21)$ & $14(6.64)$ & $6(9.84)$ & $3(4.41)$ \\
\hline \multicolumn{5}{|c|}{ Linear-by-linear association $0.1503(P=0.006)^{* * *}$} \\
\hline \multicolumn{5}{|c|}{ Gender } \\
\hline Male & $147(75.38)$ & $146(69.19)$ & $43(70.49)$ & $48(70.59)$ \\
\hline Female & $48(24.62)$ & $65(30.81)$ & $18(29.51)$ & $20(29.41)$ \\
\hline \multicolumn{5}{|c|}{ Linear-by-linear association $0.0583(P=0.602)$} \\
\hline \multicolumn{5}{|c|}{ Marital status } \\
\hline Married & $161(82.56)$ & $172(81.52)$ & $47(77.05)$ & $54(79.41)$ \\
\hline Single & $15(7.69)$ & $18(8.53)$ & $5(8.20)$ & $6(8.82)$ \\
\hline Widow & $12(6.15)$ & $15(7.11)$ & $4(6.56)$ & $4(5.88)$ \\
\hline Divorce & $4(2.05)$ & $2(0.95)$ & $3(4.92)$ & $3(4.41)$ \\
\hline Separated & $3(1.54)$ & $4(1.90)$ & $2(3.28)$ & $1(1.47)$ \\
\hline \multicolumn{5}{|c|}{ Linear-by-linear association $0.1121(P=0.100)^{*}$} \\
\hline \multicolumn{5}{|c|}{ Household size } \\
\hline$\leq 5$ & $108(55.38)$ & $115(54.50)$ & $33(54.10)$ & $45(66.18)$ \\
\hline $6-10$ & $87(44.62)$ & $96(45.50)$ & $28(45.90)$ & $23(33.82)$ \\
\hline \multicolumn{5}{|c|}{ Linear-by-linear association $0.0316(P=0.0371)^{* *}$} \\
\hline \multicolumn{5}{|l|}{ Level of education } \\
\hline No formal education & $35(17.95)$ & $40(18.96)$ & $12(19.67)$ & $12(17.65)$ \\
\hline Primary education & $37(18.97)$ & $38(18.01)$ & $7(11.48)$ & $8(11.76)$ \\
\hline Secondary education & $108(55.38)$ & $115(54.50)$ & $36(59.02)$ & $43(63.24)$ \\
\hline Post-secondary education & $15(7.69)$ & $18(8.53)$ & $6(9.84)$ & $5(7.35)$ \\
\hline \multicolumn{5}{|c|}{ Linear-by-linear association $0.4434(P=0.0014)^{* * *}$} \\
\hline \multicolumn{5}{|c|}{ Income per cropping season (US dollars) } \\
\hline$\leq 200$ & $187(95.90)$ & $202(95.73)$ & $58(95.08)$ & $63(92.65)$ \\
\hline $201-250$ & $1(0.51)$ & $1(0.47)$ & $1(1.64)$ & $1(1.47)$ \\
\hline $251-300$ & $2(1.03)$ & $2(0.95)$ & $0(0.00)$ & $0(0.00)$ \\
\hline $301-350$ & $2(1.03)$ & $3(1.42)$ & $1(1.64)$ & $3(4.41)$ \\
\hline Above 350 & $3(1.54)$ & $3(1.42)$ & $1(1.64)$ & $1(1.47)$ \\
\hline \multicolumn{5}{|c|}{ Linear-by-linear association $0.0096(P=0.0936)^{*}$} \\
\hline \multicolumn{5}{|c|}{ Secondary occupation } \\
\hline Civil servant & $31(15.90)$ & $36(17.06)$ & $15(24.59)$ & $17(25.00)$ \\
\hline Private business & $154(78.97)$ & $160(75.83)$ & $44(72.13)$ & $48(70.59)$ \\
\hline Student & $10(5.13)$ & $15(7.11)$ & $2(3.28)$ & $3(4.41)$ \\
\hline \multicolumn{5}{|c|}{ Linear-by-linear association $0.0071(P=0.1830)$} \\
\hline
\end{tabular}

Figures in parenthesis are percentage

$\$ 1=2360$

***,**,*Significant at $1 \%, 5 \%$ and $10 \%$ probability level, respectively

and cultivation, and $77.1 \%$ and $79.4 \%$ adopted the grass as a means of erosion control because of its effectiveness in erosion control and its availability, respectively.
The coefficient of household size significantly influenced the adoption of vetiver grass technology as a means of erosion control at $5 \%$ level of significance. The 
table shows that most of the respondents had household sizes that were not more than 5 members, 55.4\% of the respondents with household size within this category adopted vetiver grass as a means of erosion control because it was cheap and affordable. More than $54 \%$ of the respondents adopted the grass because of its effectiveness in erosion control and the ease of its maintenance and cultivation. In the same vein, the coefficient of level of education shows a significant relationship with the reasons of adoption of vetiver grass technology as a means of erosion control in the study area. The table reveals $55.4 \%$ of the respondents with secondary school education to have adopted vetiver grass as a means of erosion control on the fact that it was cheap and affordable; about $59 \%$ adopted the grass because of its effectiveness in erosion control and more than $63 \%$ of the respondents with secondary school education adopted the technology because it was readily available. Finally, the coefficient of income for the respondents significantly influenced the reasons for the adoption of vetiver grass technology at $10 \%$ level. The result shows that most of the respondents with income of $\$ 200$ and less had the highest percentage for the four reasons of adoption of vetiver grass presented in Table 3. About $96 \%$ of the respondents in this category adopted the use of vetiver for erosion control because of its affordability and cheap, 95.7\% adopt for the reason of its ease maintenance and cultivation, $95.1 \%$ adopt the grass technology because of its effectiveness in erosion control, and lastly $92.7 \%$ adopt it for the fact that it is readily available.

\section{Farmers' perception of the effectiveness of vetiver grass in erosion control.}

Table 4 shows the result of the perceived effects of the effectiveness of vetiver grass technology in erosion control in the study area. The result presented in Table 4 shows the farmers perception on the effectiveness of vetiver grass in erosion control. The coefficient of age was statistically significant at $10 \%$ level; about $43.68 \%$ of the farmers within the ages of 51-60 years strongly agreed on the effectiveness of vetiver grass in erosion control. Also, the result shows that $54.76 \%$ agree while only $2.63 \%$ of the respondents within the ages of 31-40 years strongly disagreed on the effectiveness of vetiver grass in erosion control.

The coefficient of gender was significant at $1 \%$ level $\left(X^{2}=0.2324, P=0.0009\right)$. Male respondents who strongly agreed on the effectiveness of vetiver grass in erosion control had the highest percentage; $32.88 \%$ agreed, and only $1.7 \%$ of the male respondents strongly disagreed on the effectiveness of vetiver grass in erosion control. The farmers' perception on the effectiveness of vetiver grass in erosion control was significantly influenced by marital status of the respondents $\left(X^{2}=0.0030, P=0.0210\right)$. About $38.7 \%$ of the farmers who were married strongly agreed on the effectiveness of vetiver grass in erosion control while $52.8 \%$ of the singles agreed and $33.4 \%$ of the divorce disagreed on the effectiveness of vetiver grass in erosion control. Also, the coefficient of level of education was significant at 5\% level. The result shows that 59.4\% of the respondents with post-secondary school education strongly agreed on the effectiveness of vetiver grass in erosion control. More than $32 \%$ of the respondents who had secondary school education agreed on the effectiveness of vetiver grass in erosion control and $2.6 \%$ of those with secondary school education completely disagreed with the effectiveness of vetiver grass in erosion control. Income $\left(X^{2}=0.2334, P=0.0301\right)$ shows a significant relationship with the effectiveness of vetiver grass in controlling erosion, and about $37 \%$ of respondents with income that is not more than $\$ 200$ strongly agree to the effectiveness of vetiver grass in controlling erosion.

\section{Farmers' usage of vetiver grass}

The result on Table 5 reveals the usage of vetiver grass by the respondents in the study area. The table shows that $56.3 \%$ of the farmers in the study area were fairly using vetiver grass for demarcation of farmland, while $43.8 \%$ were not using the grass for this purpose. Thirty-five percent were fairly using the grass as roofing material, and $14 \%$ highly used the vetiver grass for roofing, while exactly $51 \%$ of the respondents were not using the grass for roofing. The table also shows that $49.5 \%$ of the farmers were highly using the grass as pest control, $23.8 \%$ used the grass for that same purpose, and about $26.8 \%$ of the respondents were not using the grass for controlling pest. Exactly $23 \%$ highly included the grass in animal feed, $29.5 \%$ fairly include it in livestock feed formulation, while $47.5 \%$ were not using the grass for that purpose. A little above twenty $(21.8 \%)$ of the farmers highly used the grass for the herbal skin care, $17 \%$ fairly used the grass for the purpose, while $61.3 \%$ were not using it for herbal skin care. The result further showed that farmers in the study are uses vetiver grass for controlling pest as it ranked first among the various usage. It is equally essential in feeding the livestock and in the use of it as roofing materials. It use as herbal skin care was ranked fourth and for controlling erosion was ranked fifth and its use for farmland demarcation as the sixth. They proved the usefulness of the vetiver grass among the farmers, but its awareness on its potential in soil erosion control could still be improved.

\section{Farmers' source of knowledge of the use of vetiver grass}

Table 6 shows the sources of the knowledge of the use of vetiver grass as a means of erosion control. About 
Table 4 Farmers' perception of the effectiveness of vetiver grass in erosion control. Source: Field Survey, 2018

\begin{tabular}{|c|c|c|c|c|c|c|}
\hline \multirow[t]{2}{*}{ Variables } & \multicolumn{6}{|c|}{ Level of agreement } \\
\hline & Strongly agree & Agree & Undecided & Disagree & Strongly disagree & Total \\
\hline \multicolumn{7}{|l|}{ Age } \\
\hline$\leq 30$ & $6(14.29)$ & $23(54.76)$ & $11(26.19)$ & $1(2.38)$ & $1(2.38)$ & $42(100.00)$ \\
\hline $31-40$ & $41(35.96)$ & $26(22.81)$ & $39(34.21)$ & $5(4.39)$ & $3(2.63)$ & $114(100.00)$ \\
\hline $41-50$ & $45(39.47)$ & $31(27.19)$ & $33(28.95)$ & $3(2.63)$ & $2(1.75)$ & $114(100.00)$ \\
\hline $51-60$ & $38(43.68)$ & $27(31.03)$ & $17(19.54)$ & $4(4.60)$ & $1(1.15)$ & $87(100.00)$ \\
\hline Above 60 & $14(32.56)$ & $13(30.23)$ & $14(32.56)$ & $2(4.65)$ & $0(0.00)$ & $43(100.00)$ \\
\hline \multicolumn{7}{|c|}{ Linear-by-linear association $0.0066(P=0.0962)^{*}$} \\
\hline \multicolumn{7}{|c|}{ Gender } \\
\hline Male & $107(36.64)$ & $96(32.88)$ & $73(25.00)$ & $11(3.77)$ & $5(1.71)$ & $292(100.00)$ \\
\hline Female & $37(34.26)$ & $24(22.22)$ & $41(37.96)$ & $4(3.70)$ & $2(1.85)$ & $108(100.00)$ \\
\hline \multicolumn{7}{|c|}{ Linear-by-linear association $0.2324(P=0.0009)^{* * *}$} \\
\hline \multicolumn{7}{|l|}{ Marital status } \\
\hline Married & $123(38.68)$ & $89(27.99)$ & $94(29.56)$ & $7(2.20)$ & $5(1.57)$ & $318(100.00)$ \\
\hline Single & $6(16.67)$ & $19(52.78)$ & $8(22.22)$ & $2(5.56)$ & $1(2.78)$ & $36(100.00)$ \\
\hline Widow & $12(41.38)$ & $6(20.69)$ & $8(27.59)$ & $2(6.90)$ & $1(3.45)$ & $29(100.00)$ \\
\hline Divorce & $3(25.00)$ & $3(25.00)$ & $2(16.67)$ & $4(33.33)$ & $0(0.00)$ & $12(100.00)$ \\
\hline Separated & $0(0.00)$ & $3(60.00)$ & $2(40.00)$ & $0(0.00)$ & $0(0.00)$ & $5(100.00)$ \\
\hline \multicolumn{7}{|c|}{ Linear-by-linear association $0.0030(P=0.0210)^{* *}$} \\
\hline \multicolumn{7}{|c|}{ Household size } \\
\hline$\leq 5$ & $94(42.34)$ & $63(28.38)$ & $54(24.32)$ & $6(2.70)$ & $5(2.25)$ & $222(100.00)$ \\
\hline $6-10$ & $50(28.09)$ & $57(32.02)$ & $60(33.71)$ & $9(5.06)$ & $2(1.12)$ & $178(100.00)$ \\
\hline \multicolumn{7}{|c|}{ Linear-by-linear association $0.0834(P=0.5324)$} \\
\hline \multicolumn{7}{|c|}{ Level of education } \\
\hline No formal education & $26(27.08)$ & $23(23.96)$ & $40(41.67)$ & $6(6.25)$ & $1(1.04)$ & $96(100.00)$ \\
\hline Primary education & $25(31.65)$ & $25(31.65)$ & $24(30.38)$ & $5(6.33)$ & $0(0.00)$ & $79(100.00)$ \\
\hline Secondary education & $74(38.34)$ & $63(32.64)$ & $47(24.35)$ & $4(2.07)$ & $5(2.59)$ & $193(100.00)$ \\
\hline Post-secondary education & $19(59.38)$ & $9(28.13)$ & $3(9.38)$ & $0(0.00)$ & $1(3.13)$ & $32(100.00)$ \\
\hline \multicolumn{7}{|c|}{ Linear-by-linear association $0.0094(P=0.0000)^{* * *}$} \\
\hline \multicolumn{7}{|c|}{ Income per cropping season (US dollars) } \\
\hline$\leq 200$ & $136(36.46)$ & $114(30.56)$ & $102(27.35)$ & $15(4.02)$ & $6(1.61)$ & $373(100.00)$ \\
\hline $201-250$ & $1(14.29)$ & $1(14.29)$ & $4(57.14)$ & $0(0.00)$ & $1(14.29)$ & $7(100.00)$ \\
\hline $251-300$ & $3(37.50)$ & $2(25.00)$ & $3(37.50)$ & $0(0.00)$ & $0(0.00)$ & $8(100.00)$ \\
\hline $301-350$ & $2(25.00)$ & $2(25.00)$ & $4(50.00)$ & $0(0.00)$ & $0(0.00)$ & $8(100.00)$ \\
\hline Above 350 & $2(50.00)$ & $1(25.00)$ & $1(25.00)$ & $0(0.00)$ & $0(0.00)$ & $4(100.00)$ \\
\hline \multicolumn{7}{|c|}{ Linear-by-linear association $0.2334(P=0.0301)^{* *}$} \\
\hline \multicolumn{7}{|c|}{ Secondary occupation } \\
\hline Civil servant & $21(40.38)$ & $17(32.69)$ & $12(23.08)$ & $0(0.00)$ & $2(3.85)$ & $52(100.00)$ \\
\hline Private business & $122(37.08)$ & $91(27.66)$ & $97(29.48)$ & $15(4.56)$ & $4(1.22)$ & $329(100.00)$ \\
\hline Student & $1(5.26)$ & $5(26.32)$ & $12(63.16)$ & $0(0.00)$ & $1(5.26)$ & $19(100.00)$ \\
\hline \multicolumn{7}{|c|}{ Linear-by-linear association $0.4236(P=0.1411)$} \\
\hline
\end{tabular}

Figures in parenthesis are percentage

$\$ 1=360$

********Significant at $1 \%, 5 \%$ and $10 \%$ probability level, respectively

$26.5 \%$ of the respondents claimed that they sourced the knowledge of the use of vetiver grass from neighbouring farmers, more than $25 \%$ obtained the knowledge from the extension agents, and $12.3 \%$ claimed that they sourced the knowledge from both neighbouring farmers and extension agents. Exactly 6\% obtained the knowledge of the use of vetiver grass from neighbouring farmers, extension agents and media (radio, television and 
Table 5 Farmers' usage of vetiver grass. Source: Field Survey, 2018

\begin{tabular}{|c|c|c|c|c|c|}
\hline \multirow[t]{2}{*}{ Uses of vetiver } & \multicolumn{5}{|c|}{ Level of usage of vetiver grass } \\
\hline & Highly used & Fairly used & Not used & Weighted mean & Rank \\
\hline Demarcation of farmlands & $0(0.00)$ & $225(56.25)$ & $175(43.75)$ & 208.33 & 6 \\
\hline Roofing materials & $56(14.00)$ & $140(35.00)$ & $204(51.00)$ & 217.33 & 3 \\
\hline Pest control & $193(49.50)$ & 95 (23.75) & $107(26.75)$ & 292.0 & 1 \\
\hline Erosion control & $63(15.75)$ & $114(28.50)$ & $223(55.75)$ & 213.33 & 5 \\
\hline Animal feeds & $92(23.00)$ & $118(29.50)$ & $190(47.50)$ & 234.0 & 2 \\
\hline Herbal skin care & $87(21.75)$ & $68(17.00)$ & $245(61.25)$ & 214 & 4 \\
\hline
\end{tabular}

Figures in parenthesis are percentage

Table 6 Farmers' source of knowledge of the use of vetiver grass. Source: Field Survey, 2018

\begin{tabular}{lcc}
\hline Sources of usage knowledge & Frequency & Percentage \\
\hline No knowledge & 97 & 24.25 \\
Neighbouring farmers & 106 & 26.50 \\
Extension agent & 101 & 25.25 \\
Media & 11 & 2.75 \\
Internet & 12 & 3.00 \\
Neighbouring farmers and extension agent & 49 & 12.25 \\
Neighbouring farmers, extension agent and & 24 & 6.00 \\
$\quad$ media & & \\
\hline
\end{tabular}

newspapers), $3 \%$ from the internet and $2.8 \%$ from media only.

Farmers' perception of the major type of damage erosion poses on cultivated crops and farmlands

The farmers' perception on the major types of damages caused by erosion on farmlands is shown on Table 7. The coefficient of age, gender, household size and level of education significantly influenced the perception of the farmers on the damages caused by erosion on agricultural farmland. The result shows that $28.8 \%$ farmers within the ages of 31-40 years claimed that erosion reduced soil fertility, $29.8 \%$ claimed that it caused gully on the farmland, and more than $28 \%$ claimed that it caused both destruction of farm pathways and reduced crop yield. More than $70 \%$ of the male farmers claimed that erosion caused reduction in soil fertility, gully, destruction in farm pathways and reduction in crop yield, and predisposed the farm to other pests. Also, the result shows that more than $50 \%$ of the farmers with household size that was not more than 5 members claimed that erosion caused reduction in soil fertility, gully, destruction in farm pathways and reduction in crop yield, and predisposed the farm to other pests. Exactly $48.8 \%$ of the respondents with postsecondary education claimed that erosion caused reduction in soil fertility, $47.6 \%$ claimed that it destroyed farm pathways, $46.3 \%$ claimed that it reduced crop yield, while 49.4\% claimed that erosion predisposed cultivated crops to other pests.

\section{Discussion}

The result presented in Table 1 shows that most of the farmers were still in their active and productive ages. The result equally reveals that male were more than female farmers in the study area. This result contradicts Ejiogu and Offor (2009) in their study on the assessment of the use of vetiver grass in sheet erosion management in Imo State, Nigeria, because the male dominated farming in the study area as a result of low access of their female counterpart to productive assets. The household size was considerably moderate and member of the family could serve in the place of family labour for agricultural production. With secondary school education having the highest percentage of the respondents, the adoption of vetiver grass technology may not be constrained by the level of education of the respondents in the study area. That implies that the adoption of new agricultural innovation (s) will not be difficult. The average income of the respondents also suggests that most of the farmers were low income earners; this might be as result of their scale of production as most of them were smallholder farmers. With more than $80 \%$ of the respondents having private businesses to augment their primary sources of livelihood, it was evident that diversification to these businesses was aimed to mitigate the ripple effects of food insecurity in the study area.

According to Table 2, most of the respondents who were within the age limit of 41 and 50 years were aware of the use of vetiver grass technology as a means of erosion control in the study area. This suggests the high level of the awareness of the vetiver grass among farmers; this will aid their productivity and management of erosion in the study area. More male farmers were aware of the vetiver grass technology than the female in the study area. The dominance of male in agricultural production and 
Table 7 Farmers' perception of the major type of damage caused by erosion on crops on farmland. Source: Field Survey, 2018

\begin{tabular}{|c|c|c|c|c|c|}
\hline \multirow[t]{2}{*}{ Variables } & \multicolumn{5}{|c|}{ Perceived type of damage caused by erosion } \\
\hline & $\begin{array}{l}\text { Reduction } \\
\text { of soil fertility }\end{array}$ & Caused gully & $\begin{array}{l}\text { Caused farm } \\
\text { pathway } \\
\text { destruction }\end{array}$ & Reduced crop yield & $\begin{array}{l}\text { Predisposed } \\
\text { farm to other } \\
\text { pest }\end{array}$ \\
\hline \multicolumn{6}{|l|}{ Age } \\
\hline$\leq 30$ & $42(10.80)$ & $36(9.50)$ & 39 (10.08) & 37 (10.08) & $33(10.38)$ \\
\hline $31-40$ & $112(28.79)$ & $113(29.82)$ & $110(28.42)$ & $105(28.61)$ & $83(26.10)$ \\
\hline $41-50$ & $110(28.28)$ & $107(28.23)$ & $112(28.94)$ & $106(28.88)$ & $94(29.56)$ \\
\hline $51-60$ & $86(22.11)$ & $83(21.90)$ & $85(21.96)$ & $81(22.07)$ & $72(22.64)$ \\
\hline Above 60 & $39(10.03)$ & $40(10.55)$ & $41(10.59)$ & $38(10.35)$ & $36(11.32)$ \\
\hline \multicolumn{6}{|c|}{ Linear-by-linear association $0.1503(P=0.006)^{* * *}$} \\
\hline \multicolumn{6}{|l|}{ Gender } \\
\hline Male & $287(73.78)$ & $276(72.82)$ & $283(73.13)$ & $269(73.30)$ & $239(75.16)$ \\
\hline Female & $102(26.22)$ & $103(27.18)$ & $104(26.87)$ & $98(26.70)$ & $79(24.84)$ \\
\hline \multicolumn{6}{|c|}{ Linear-by-linear association $0.0583(P=0.602)$} \\
\hline \multicolumn{6}{|c|}{ Marital status } \\
\hline Married & $311(79.95)$ & $307(81.00)$ & $309(79.84)$ & $290(79.02)$ & $257(80.82)$ \\
\hline Single & $35(9.00)$ & $31(8.18)$ & $33(8.53)$ & $34(9.26)$ & $30(9.43)$ \\
\hline Widow & $27(6.94)$ & $27(7.12)$ & $28(7.24)$ & $28(7.63)$ & $18(5.66)$ \\
\hline Divorce & $11(2.83)$ & $11(2.90)$ & $12(3.10)$ & $11(3.00)$ & $10(3.14)$ \\
\hline Separated & $5(1.29)$ & $3(0.79)$ & $5(1.29)$ & $4(1.09)$ & $3(0.94)$ \\
\hline \multicolumn{6}{|c|}{ Linear-by-linear association $0.1121(P=0.100)^{*}$} \\
\hline \multicolumn{6}{|c|}{ Household size } \\
\hline$\leq 5$ & $218(56.04)$ & $212(55.94)$ & $214(55.30)$ & $204(55.59)$ & $183(57.55)$ \\
\hline $6-10$ & $171(43.96)$ & $167(44.06)$ & $173(44.70)$ & $163(44.41)$ & $135(42.45)$ \\
\hline \multicolumn{6}{|c|}{ Linear-by-linear association $0.0316(P=0.0371)^{* *}$} \\
\hline \multicolumn{6}{|c|}{ Level of education } \\
\hline No formal education & $92(23.65)$ & $92(24.27)$ & $95(24.55)$ & $91(24.80)$ & $74(23.27)$ \\
\hline Primary education & $76(19.54)$ & $75(19.79)$ & $76(19.64)$ & $75(20.44)$ & $64(20.13)$ \\
\hline Secondary education & $190(48.84)$ & $182(48.02)$ & $184(47.55)$ & $170(46.32)$ & $157(49.37)$ \\
\hline Post-secondary education & $31(7.97)$ & $30(7.92)$ & $32(8.27)$ & $31(8.45)$ & $23(7.23)$ \\
\hline \multicolumn{6}{|c|}{ Linear-by-linear association $0.4434(P=0.0014)^{* * *}$} \\
\hline \multicolumn{6}{|c|}{ Income per cropping season (Naira) } \\
\hline$\leq 200$ & $362(93.06)$ & $354(93.40)$ & $361(93.28)$ & $343(93.46)$ & $294(92.45)$ \\
\hline $201-250$ & $7(1.80)$ & $6(1.58)$ & $7(1.81)$ & $5(1.36)$ & $5(1.57)$ \\
\hline $251-300$ & $8(2.06)$ & $8(2.11)$ & $8(2.07)$ & $8(2.18)$ & $8(2.52)$ \\
\hline $301-350$ & $8(2.06)$ & $8(2.11)$ & $8(2.07)$ & $8(2.18)$ & $8(2.52)$ \\
\hline Above 350 & $4(1.03)$ & $3(0.79)$ & $3(0.78)$ & $3(0.82)$ & $3(0.94)$ \\
\hline \multicolumn{6}{|c|}{ Linear-by-linear association $0.0096(P=0.0936)^{*}$} \\
\hline \multicolumn{6}{|l|}{ Secondary occupation } \\
\hline Civil servant & $52(13.37)$ & $48(12.66)$ & $51(13.18)$ & $45(12.26)$ & $37(11.64)$ \\
\hline Private business & $320(82.26)$ & $316(83.38)$ & $320(82.69)$ & $304(82.83)$ & $267(83.96)$ \\
\hline Student & $17(4.37)$ & $15(3.96)$ & $16(4.13)$ & $18(4.90)$ & $14(4.40)$ \\
\hline Linear-by-linear association $C$ & & & & & \\
\hline
\end{tabular}

Figures in parenthesis are percentage

$\$ 1=$ \# 360

$* * * * *$, Significant at $1 \%, 5 \%$ and $10 \%$ probability level, respectively 
the insufficient access to productive assets of the female counterpart could have been the reason of low awareness of the innovation by the female farmers in the study area. Alimba and Akubuilo (2000) argued that access to productive assets such as land is a serious determinant of adoption of some technologies that could be of a longterm benefit to farmers. A large proportion of the married farmers were aware of the use of vetiver grass as a means of erosion control and the level of education of the respondents supported the level of awareness of the potentials of vetiver grass as a means of erosion control among the respondents. Studies (Chirwa 2005; Idrisa et al. 2012) have established the relationship of education and adoption of agricultural technologies. The same way Oladosu and Okunade (2006) posited that education could fuel farmers' right perception on problems facing agriculture and the possible way out of the problems; Adugna et al. (2019) suggested that the educational status of the farmers plays a vital role in the understanding of their environment. Also, the average income of the respondents was low as most of the farmers earned slightly above $\$ 84$ per production season. However, the result corroborates the findings of Ogunbameru and Idrisa (2013) where most of the respondents interviewed for their study earned above $\$ 83$ per production season, but it should be noted that the result affirms that most of the farmers in the study area were smallholder farmers. That is, they cultivated less than 5 hectares of land and relied on their production for family consumption.

The coefficient of age, marital status, household size and income significantly influenced the reasons of adoption of vetiver grass as a means of erosion control in the study area. According to Table 3, most of the farmers were still in their active and productive age. In the quest for improving productivity through adoption of improved agricultural technologies to combat existing problems, young farmers adopted vetiver grass technology for the reason of its affordability, ease in cultivation and maintenance, effectiveness in erosion control and its availability. The instance of these factors could have aid the adoption of the technology of vetiver grass as a means for erosion control. Oyewole and Ojeleye. (2015) and Castano et al. (2002) opined that new innovation in agricultural development will attract little value unless they can be put to use for the social and economic well-being of the recipients. It implies that the technology should be related to the institutional, economical, physical and social factor affecting farm and farmers.

Table 4 shows the result of the perceived effect of the effectiveness of vetiver grass technology in erosion control in the study area. The report of Kumar and Nikhil (2016) indicates the effectiveness of vetiver grass as it reduced rainfall runoff by $70 \%$ and sediment by about $90 \%$. The number of farmers who agreed to the vetiver grass' effectiveness in erosion control outweighed the number of those that disagreed, based on the age category of the farmers. Also, the percentage of the male farmers that strongly agreed and agreed to the perception of the effectiveness of vetiver grass in erosion control was higher than that of their female counterpart. This indicates that a considerable number of farmers in the study area regardless of their gender, marital status, income, level of education and household size had ratified the effectiveness of vetiver grass in erosion control in the study area. In a recent study, Adugna et al. (2019) observed that their respondents believed an improved productivity due to adoption and acceptability of vetiver grass for soil erosion control.

Vetiver grass was used for demarcation of farmland, roofing material, pest control, animal feed and herbal skin care. From the result presented in Table 5, most of the farmers used vetiver grass for demarcation of farmland, roofing, pest control, animal feed and herbal skin care; this arose from the fact that the grass is easy to cultivate, effective, cheap and it can withstand animal browsing and trampling. In a recent study by Ewetola et al. (2017), the respondents indicated their perception of vetiver grass for termite's control on their farmlands. Alemu (2008) opined that the grass could be used for rehabilitation of gullies and watershed, road cuts and river bank and dam side protection, forage and wet land protection.

Furthermore, most of the respondents in the study area have the knowledge of the use of vetiver grass from neighbouring farmers, extension agents and media (newspaper, radio and television). The essential benefits of vetiver grass enhanced the awareness and adoption of the grass in the study area, that is, the popularity of the grass based on its usefulness. Adugna et al. (2019) suggested the use of this fire and drought resistant grass to combat soil loss.

The study revealed the farmers' perception on the major types of damages caused by erosion on farmland as shown on Table 7. The coefficient of age, gender, household size and level of education significantly related with the perception of the farmers on the damages caused by erosion on agricultural farmland. The result clearly shows that most of the farmers claimed that erosion cause reduction in soil fertility, cause gully, destruction in farm pathways and reduction in crop yield and predispose farm to other pests (Tessema 2008 and Alemu 2008). World Bank (1990) posited that vetiver grass has, in no doubt shows prospects in curbing erosive land degradation in a wide range of climatic environment. 


\section{Conclusions and recommendations}

This study reveals that there was awareness of the attendant danger of soil erosion on the respondent's farmlands. The majority that knew the effectiveness of vetiver grass in erosion was those whose secondary occupation was private business. The respondents who had the awareness of vetiver grass as erosion control measure were within their active and productive age. The majority of the farmers who adopted vetiver grass in controlling soil erosion was influenced by education and sex which was predominantly male. The result further showed that most of the respondents uses vetiver for pest control, followed by the use of it in the making of animal feed and as roofing material.

From the findings of this research, the following recommendations are made (a) the extension agents should create more awareness for the farmers to adopt the vetiver grass technology in order to conserve the soil, water and nutrients on their farmlands. (b) They should educate them about the risk and damages that could be done on their farmlands without the vetiver grass. (c) All other benefits from vetiver grass such as vetiver clippings for mulch and compost in order to boost fertility, etc., could be explored by the farmers because the technology is simple, cheap and eco-friendly.

\section{Abbreviations \\ LAUTECH: Ladoke Akintola University of Technology; LGAs: Local Government Area.}

\section{Acknowledgements}

The authors appreciate the effort of Dr. K.Y. Ogunleye in the field assessment and Dr S.A Babarinde for the editorial work of the manuscript

\section{Authors' contributions}

$A E$, FM, NM and AA were involved in conceptualization; $A E$, IT and GE helped in design of the work; GE, NM, AA and KA contributed to the acquisition and analysis; $A E, A A$ and $G E$ were involved in interpretation of data; $A E, G E, K A$ and FM helped in writing-Original draft. For the process of publication, all authors read and approved the final manuscript.

\section{Funding}

Not applicable.

Availability of data and materials
https:/data.mendeley.com/datasets.

Ethics approval and consent to participate

Not applicable.

\section{Consent for publication}

Not applicable.

\section{Competing interests}

The authors declare that they have no competing interests.

\section{Author details}

${ }^{1}$ Department of Crop Production and Soil Science, Ladoke Akintola University of Technology, P.M.B 4000, LAUTECH, Ogbomoso, Oyo State, Nigeria. ${ }^{2}$ Department of Agricultural Economics, Ladoke Akintola University of Technology, Ogbomoso, Nigeria.
Received: 13 June 2020 Accepted: 29 December 2020

Published online: 22 January 2021

\section{References}

Adugna O, Alemu D, Melkamu T (2019) Evaluation of vetiver grass (Vetiver zizanioides) potential to soil erosion control at Assosa, Benishangul Gumuz, Ethiopia. Int J Environ Sci Nat Res 16(1):033-038

Alemu M (2008) Report on vetiver grass technology programme. Integrated Food Security Project. Amhara Regional State Ethiopia

Aina PO (1989) Soil erosion problem in Nigeria. Issue and perspectives of soil management and Conservation. In: Proceedings of the 17th annual conference of the Soil Science Society of Nigeria, pp 6-25

Akamigbo FOR (1988) Soil conservation and erosion problems in continuous food production. Proceedings of the 16th annual conference of the Soil Science Society of Nigeria Minna, Niger State. November, 16, pp 1-13

Alimba J, Akubuilo, C (2000) Consequences of technological change on farm enterprises in South eastern Nigeria: implications for agricultural transformation. In: Nwosu AC, Nwajiuba CU, Mbanasor JA (eds) Agricultural transformation in Nigeria. Proceedings of a national conference in honour of Professor Martin. O. ljere. Novelty Industrial enterprises limited 124A Okigwe Road, Owerri Imo State

Angima SD, Stott DE, O'Neill MK, Ong CK, Weesies GA (2003) Soil erosion prediction using RUSLE for central Kenyan highland conditions. Agric Ecosyst Environ 97:295-308

Babalola O, Opara-Nadi OA (1993) Tillage systems and soil properties in West Africa. Soil Tillage Res 27:149-174

Babalola O, Jimba SC, Maduakolam O, Dada OA (2003) Use of vetiver grass for soil and water conservation in Nigeria. In: Proceedings of the 3 rd international conference on vetiver and exhibition. Vetiver and Water, Guangzhou, China, October 2003. China Agricultural Press, Beijing

Biswas H, Raizada A, Mandal D, Kumar S, Srinivas S, Mishra PK (2015) Identification of are as vulnerable to soil erosion risk in India using GIS methods. Solid Earth 6:1247-1257

Cao L, Zhang Y, Lu H, Yuan J, Zhu Y, Liang Y (2016) Grass hedge effects on controlling soil loss from concentrated flow: a case study in the red soil region of China. Soil Tillage Res 148:97-105

Castano J, Meulenberg MTG, Tilburg V (2002) A new method of measuring the adoption of soil conservation practices; theory and application. Neth J Agric Sci 50:95-114

Chirwa EW (2005) Adoption of fertilizer and hybrid seeds by smallholder maize farmers in southern Malawi. Dev Southern Afr 22(1):1-12

Colazo JC, Buschiazzo D (2015) The impact of agriculture on soil texture due to wind erosion. Land Degrad Dev 26:62-70

Edeoghon CO, Ajayi MT, Ugboya TO (2008) Awareness and use of sustainable agricultural practices by arable crop farmers in Ikpoba Okha Local Government Area of Edo State. J Sustain Dev Agric Environ 3(2):55-63

Ejiogu AO, Offor IR (2009) Assessment of the use of vetiver grass (Vetiveria zizanioides) in sheet erosion management in Imo State. Paper presented at the 9th global conference on business \& economics (GCBE), October 16-17, 2009. Cambridge University, Cambridge, UK

Ewetola EA (2017) Quantifying tillage and vetiver grass (Vetiveria nigritana Stapf) strips spacing effects on runoff, soil loss and maize yield in Southern guinea savanna of Nigeria. J Northeast Agric Univ (Engl Ed) 24(4):1-18

Ewetola EA, Babarinde SA, Omirin T, Ojewole DO (2017) Farmers' perception of the usefulness of vetiver grass for termite control on Ogbomoso Agricultural Zone Farmlands, South-Western Nigeria. J King Saud Univ Sci. https ://doi.org/10.1016/j.jksus.2017.01.002

Greenfield JC (2002) Vertiver grass: an essential grass for the conservation of planet. Infinity Publishing Com, West Conshohocken

Idrisa YL, Ogunbameru BO, Shehu H (2012) Effects of adoption of improved maize seed on household food security in Gwoza Local Government area of Borno State, Nigeria. Agric Sci Res J 2(2):70-76

Katsuyuki M (2009) Soil and humanity: culture, civilization, livelihood and health. Soil Sci Plant Nutr 55:603-615

Kumar D, Nikhil K (2016) Vetiver grass for manifold uses: a critical review. Int J Eng Tech Res 4(2):146-152

Keesstra S, Pereira P, Novara A, Brevik EC, Azorin-Molina C, Parras-Alcántara L, Jordán A, Cerdà A (2016) Effects of soil management techniques on soil water erosion in apricot orchards. Sci Total Environ 551:357-366 
Ligonja PJ, Shrestha RP (2015) Soil erosion assessment in Kondoa eroded area in Tanzania using universal soil loss equation, geographic information systems and socio- economic approach. Land Degrad Dev 26:367-379

Molla T, Sisheber B (2017) Estimating soil erosion risk and evaluating erosion control measures for soil conservation planning at Koga watershed in highlands of Ethiopia. Solid Earth 8:13-25

Ogunbameru BO, Idrisa YL (2013) Empowering small-scale farmers through improved technology adoption: a case study of Soybean farmers in Borno State, Nigeria. J Agric Ext 17(1):144-151

Oku EF, Aiyelari EA (2014) Green technology for keeping soil water- nutrient fluxes on cultivated steep land and for mitigating the consequences of climate change. J Agric Environ Int Dev 108(1):17-27

Oladosu 1O, Okunade EO (2006) Perception of village extension agents in disseminating agricultural information in Oyo Agricultural Zone of Oyo State. J Soc Sci 12(3):187-191

Osuji GE, Babalola AO (1982) Tillage practices on a tropical soil. J Environ Manag 14:343-348

Oyewole SO, Ojeleye OA (2015) Factors influencing the use of improved farm practices among small scale farmers in Kano, Nigeria. Net J Agric Sci $3(1): 1-4$

Prosdocimi M, Cerdà A, Tarolli P (2016) Soil water erosion on Mediterranean vineyards: a review. CATENA 141:1-21
Rodrigo-Comino J, Brings C, Lassu T, Iserloh T, Senciales JM, Martínez Murillo JF, Ruiz Sinoga JD, Seeger M, Ries JB (2015) Rainfall and human activity impacts on soil losses and rill erosion in vineyards (Ruwer Valley, Germany). Solid Earth 6:823-837

Sanguankaeo S, Sawadimongkol L, Jirawanwasana P (2011) Sustainable vetiver system in erosion control and stabilization for highways slope in Thailand. In: Proceedings of the $5^{\text {th }}$ international conference on Vetiver, Lucknow, India

Tessema C (2008) Project Proposal on Vetiver Promotion in the Amhara Regional State-Ethiopia

Truong PNV, Loch R (2004) Vetiver system for erosion and sediment control. In: ISCO $13^{\text {th }}$ international soil conservation organization conference, Brisbane

World Bank (1990) Vetiver grass: the hedge against erosion, 3rd edn. World Bank, Washington, p 78

\section{Publisher's Note}

Springer Nature remains neutral with regard to jurisdictional claims in published maps and institutional affiliations.

\section{Submit your manuscript to a SpringerOpen ${ }^{\circ}$ journal and benefit from:}

- Convenient online submission

- Rigorous peer review

- Open access: articles freely available online

- High visibility within the field

- Retaining the copyright to your article

Submit your next manuscript at $\boldsymbol{\nabla}$ springeropen.com 